INTERNATIONAL JOURNAL OF INNOVATION IN ENTERPRISE SYSTEM

Journal homepage: https://ijies.sie.telkomuniversity.ac.id

e-ISSN: 2580-3050, DOI: https://doi.org/10.25124/ijies.v6i01.155

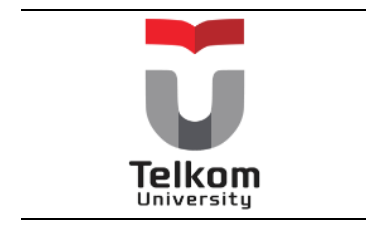

\title{
Design Business Offline and Online Based on Website of Pikyeum SME in Bandung
}

Dinda Syabila Elfani ${ }^{1}$, Endang Chumaidiyah ${ }^{2 *}$, Sinta Aryani ${ }^{3}$

${ }^{1}$ School of Industrial and System Engineering

Telkom University, Bandung, Indonesia

dindasyabila1999@gmail.com

${ }^{2}$ School of Industrial and System Engineering

Telkom University, Bandung, Indonesia

endangchumaidiyah@telkomuniversity.ac.id

${ }^{3}$ School of Industrial and System Engineering

Telkom University, Bandung, Indonesia

sintatelu@telkomuniversity.ac.id

*endangchumaidiyah@telkomuniversity.ac.id

\section{ARTICLE INFO}

Article history:

Received 23 August 2021

Accepted 14 September 2021

Published 31 January 2022
Keywords:

Design Business;

Peuyeum; Indonesian

Food; Feasibility;

Sensitivity
ABSTRACT

Pikyeum SME created a new business idea to connect sellers and consumers, introduce products, and place online purchases. By creating a website, Pikyeum SME makes it easy for consumers throughout Indonesia to find Peuyeum chips. This case study was conducted in Pikyeum SME, located in Lot Leuwidulang No. C 02, Sub-district Pameungpeuk, Bandung, Indonesia. Data collection and analysis were conducted qualitatively and quantitatively. The purpose of this research is to measure the demand, design technical and operational aspects, design a websitebased application, measure the product's financial feasibility, and measure the sensitivity level of Pikyeum food products offline and online sales. Survey data were analyzed using corrected itemtotal correlation as a validity testing technique and Cronbach's Alpha as a reliability testing technique with the aid of the SPSS program. Based on this research, Net Present Value (NPV) is IDR 167.006.461, Interest Rate of Return (IRR) at 36,70\%, and Payback Period at 3,4 years. It can be concluded that Pikyeum SME is feasible to run because NPV $>0$, payback period < asset economic life, and IRR $>$ MARR. The increase of raw materials and packaging costs shouldn't be more than $36,76 \%$. Meanwhile, the increase of labor cost shouldn't be more than $23,51 \%$. The demand decreases shouldn't be more than $15,63 \%$ and selling prices shouldn't exceed $11,34 \%$.

This is an open-access article under the $\mathrm{CCBY-NC-SA}$ license.

\section{INTRODUCTION}

Cassava is one of the staple food sources good for consumption because it is rich in carbohydrates and is gluten-free, grain-free, and nut-free. According to Ahmad Fahtoni, one of the researchers from the Center for Agricultural Biotechnology, Indonesian Institute of Sciences (LIPI), specializing in cassava, the demand for cassava-based foodstuffs in Indonesia is increasing. In 2016, the Food and Agriculture Organization (FAO) noted that Indonesia is one of the largest cassava producers in the world, ranking 4th. Based on average per capita consumption data a week for several important foodstuffs in Indonesia in 2007-2019 [1], Indonesian people prefer cassava to sweet potato. Of the 34 provinces in Indonesia, West Java is the 4th largest cassava producer in Indonesia. The abundance of cassava in West Java has inspired people to use cassava as food. 
One of the indigenous foods of Bandung is peuyeum. Peuyeum is a fermented cassava product that expired in 2-3 days. With these conditions, Pikyeum SME located in Bandung, Indonesia was motivated to process peuyeum into chips that the public can enjoy without worrying about its expiration.

According to the [2], There are 6140 SMEs with six categories: food, fashion, trade, handicrafts, services, et cetera. The type of food business occupies the first position with 1533 SMEs. So, food is the most dominant type of business than other types. Pikyeum SME since 2016 been engaged in the snack food sector. Pikyeum SME is the first company in Indonesia were selling peuyeum chips. The company gets the Top 100 of The Big Start Indonesia Seasons 3 organized by blibli.com. The purpose of the Pikyeum SME is for all Indonesian people to enjoy peuyeum food without worrying about its durability because it can last \pm 9 months. Pikyeum has three flavor variants (original, milk, and chocolate) at IDR 22.500/pcs. Unfortunately, Pikyeum SME only distributes Pikyeum products to several stores in Indonesia.

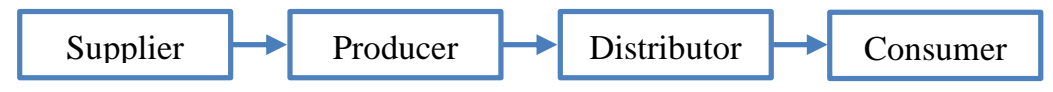

Figure 1 - Supply Chain of Pikyeum SME

According to Figure 1, Pikyeum SMEs do not directly sell products to consumers, but through distributors. The following is a list of distributor shops:

1. Lembang area: Serba susu, Pabrik bolu susu lembang, KSPBU Lembang, Rumah sosis, and Farmhouse Susu Lembang.

2. Ciwidey area: Pia kawitan.

3. Pangalengan area: Pia Kawitan.

4. Cihampelas area: Snack Jawa, Ojolali, Ojolali 126, Nonie.

5. Pasteur area: Bancris, Kabita, Kunafe.

6. Rest area: Serba Susu, Citra Rasa, dan Khazna.

7. Dago area: Toko oleh-oleh Bandung.

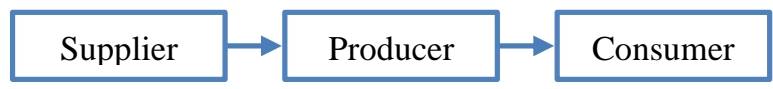

Figure 2 - Supply Chain of Pikyeum SME Based on Website

The internet makes it easy for users to get information and facilitate communication throughout the world. The internet also makes it easier for someone to buy products near or far. With that benefit, an opportunity arose to create a websitebased online business for Pikyeum. According to Figure 2, The website aims to connect directly between producers and consumers so that Pikyeum SME can sell Peuyeum chips to all Indonesian people.

The purpose of this research is to measure the demand, design technical and operational aspects, design a website-based application, measure the product's financial feasibility, and measure the sensitivity level of Pikyeum food products offline and online sales. This research explains three aspects of the feasibility study: market, technical, and financial aspects. And sensitivity analysis in raw materials costs, packaging costs, labor cost, demands, and selling prices. This study has several limitations: 1) interest rates, inflation rates, and economic conditions were considered normal and stable during the research process. 2) The scope of the research is only conducted in Java Province. 3) Feasibility analysis is only based on market aspects, technical aspects, and financial aspects. 4) The research is carried out until the planning limit, not until the implementation stage. After processing and analyzing the data, the offline and online business design based on the Pikyeum SME in Bandung is feasible because net present value $>0$, payback period < minimum of economic life asset, and interest rate of return $>$ MARR.

In this research, the system design is part of the technical aspect, one of the feasibility study methods. The design system aims to design a website used as a Pikyeum SME online sales platform. The costs incurred for the creation of the website are part of the intangible investment asset

The feasibility study is research on a business to find out whether the company is feasible or not. A business can be feasible if the business provides greater benefits than the costs incurred, such as financial and non-financial benefits. Each stage of the feasibility study has aspects that must be researched, measured, and assessed. For some cases, several aspects are not reviewed in the feasibility study considering the urgency. In general, five aspects in the feasibility study [3]: market aspect, technical aspect, management aspect, financial aspect, and socio-economic and environmental. In this study, the aspects reviewed are market aspects, technical aspects, and financial aspects.

The market aspect is the core of the feasibility study, which assesses the market potential and market share of the products offered. The company's objectives are to examine market aspects to increase sales and company profits, dominate the market, reduce competitors, increase the prestige of certain products in the market, and meet certain parties. In this study, two markets must consider:

1. The potential market serves to determine consumer interest in product offerings.

2. The available market serves to determine the interest and ability of consumers to purchase the products offered. 
The technical aspect examines the accuracy of the location, production area, and machines. Determining the right business location will positively impact the form of financial and non-financial benefits for the company. Two variables that must consider choosing a business location are the main variable (primary) and non-main variable (secondary). These two groups can change groups according to the main characteristics of the output and business projects.

The main variables (primary) are the availability of raw materials, proximity to markets and consumers, electricity and water, labor supply, and availability of facilities and infrastructure. The non-main (secondary) variables are government law, climate and soil conditions, cultural conditions in the local area, and ease of expansion/expansion.

The purpose of reviewing the financial aspect is to assess the company's overall finances to determine whether the investment is feasible to run. The things evaluated in the financial aspect are sources of funds, the need for investment costs, estimated income and investment costs for several periods, investment assessment criteria, balance sheet projections and profit/loss for future periods, and financial ratios.

Companies need investments for a relatively long period. The source of business funding obtained by the company can be from various sources such as own capital and loan capital. According to [4], own capital is capital obtained from company owners by issuing shares either privately (internally with previous shareholders) or openly (sales of shares to the public). Loan capital or foreign capital is capital obtained by the company by borrowing from various outside parties to meet needs. Source of fund for loan capital obtained from banks, non-banking financial institutions, or non-banking companies.

System design is a practical field that requires skill and creative power but cannot be determined mechanically. The system's design can be successful if the system designed is successfully implemented or the success of the information system (information system success). Modeling is the process of designing software before coding [5]. Researchers used two modelings: Data Flow Diagrams (DFD) and Use Case Diagrams. Data Flow Diagrams are charts that display system processes, flows between processes and sources, destinations, and data stored. Meanwhile, Use Case Diagram serves to determine the relationship between actors so that it is easy to find out the activities and functions of the website system.

\section{METHOD}

State of art is a reference that is used for current research from various aspects such as topics, similarities in methods, problems, or research objects.

Table 1 - State of Art

\begin{tabular}{|c|c|c|c|}
\hline No. & Title & Sources & Methods \\
\hline 1. & $\begin{array}{l}\text { Feasibility Analysis of Mobile Carwash } \\
\text { Business in Bandung }\end{array}$ & 5] & $\begin{array}{l}\text { This research explains five aspects in the feasibility study: } \\
\text { market aspect, technical aspect, management aspect, } \\
\text { financial aspect, socio-economic and environmental. }\end{array}$ \\
\hline 2. & $\begin{array}{l}\text { Feasibility Analysis of RDA Hijab } \\
\text { Business Development with Online and } \\
\text { Offline Sales }\end{array}$ & [7] & $\begin{array}{l}\text { This research explains three aspects of the feasibility } \\
\text { study: market aspect, technical aspect, and financial } \\
\text { aspect. Also, sensitivity analysis and risk analysis. }\end{array}$ \\
\hline 3. & $\begin{array}{l}\text { Feasibility Analysis and Website } \\
\text { Application Design for Digital Creative } \\
\text { Photography Startups Based on Market } \\
\text { Aspects, Technical Aspects and } \\
\text { Financial Aspects }\end{array}$ & [8] & $\begin{array}{l}\text { This research explains three aspects of the feasibility } \\
\text { study: market aspect, technical aspect, and financial } \\
\text { aspect. Also, sensitivity analysis in labor costs, demand, } \\
\text { selling price, and assets costs. }\end{array}$ \\
\hline 4. & $\begin{array}{l}\text { Street Food Business Feasibility } \\
\text { Analysis for Modern Market Parking } \\
\text { Area Utilization }\end{array}$ & [9] & $\begin{array}{l}\text { This research explains three aspects of the feasibility } \\
\text { study: market aspect, technical aspect, and financial } \\
\text { aspect. Also, sensitivity analysis in rental costs and risk } \\
\text { analysis. }\end{array}$ \\
\hline 5. & $\begin{array}{l}\text { Feasibility Analysis of Rumah Tempe } \\
\text { Zanada Establishment in Bandung } \\
\text { Using Net Present Value, Internal Rate } \\
\text { of Return, And Payback Period }\end{array}$ & [10] & $\begin{array}{l}\text { This research explains three aspects of the feasibility } \\
\text { study: market aspect, technical aspect, and financial } \\
\text { aspect. Also, sensitivity analysis in income, operating } \\
\text { costs, material costs, and direct labor cost. }\end{array}$ \\
\hline 6. & $\begin{array}{l}\text { Feasibility Analysis of Culinary } \\
\text { Business Cafe Nusantara Development } \\
\text { in the Central of Jakarta }\end{array}$ & {$[11]$} & $\begin{array}{l}\text { This research explains three aspects of the feasibility } \\
\text { study: market aspect, technical aspect, and financial } \\
\text { aspect. Also, sensitivity analysis in raw material costs, } \\
\text { labor costs, operational costs, and decrease in the level of } \\
\text { sales. }\end{array}$ \\
\hline 7. & $\begin{array}{l}\text { Feasibility Analysis on the } \\
\text { Development of Steel Sheet Zinc Plated }\end{array}$ & [12] & $\begin{array}{l}\text { This research explains three aspects of the feasibility } \\
\text { study: market aspect, technical aspect, and environmental }\end{array}$ \\
\hline
\end{tabular}




\begin{tabular}{|c|c|c|c|}
\hline & $\begin{array}{l}\text { and Galvalum Production Factory PT. S } \\
\text { Steel }\end{array}$ & & $\begin{array}{l}\text { aspect. Also, sensitivity analysis in raw material costs, } \\
\text { selling price, and increase of dollar price. }\end{array}$ \\
\hline 8. & $\begin{array}{l}\text { Business Design and Feasibility of Puru } \\
\text { Kambera Muslim Fashion Offline Store } \\
\text { Establishment }\end{array}$ & [13] & $\begin{array}{l}\text { This research explains two aspects of the feasibility study: } \\
\text { market aspect and technical aspect. Also, sensitivity } \\
\text { analysis in product costs, selling prices, and demand. }\end{array}$ \\
\hline 9. & $\begin{array}{l}\text { Business Design and Risk Analysis of } \\
\text { Sonja Coffee Shop with the Concept of } \\
\text { Coworking Space }\end{array}$ & [14] & $\begin{array}{l}\text { This research explains three aspects of the feasibility } \\
\text { study: market aspect, technical aspect, and financial } \\
\text { aspect. Also, sensitivity analysis (raw material costs, } \\
\text { labor costs, demand, and sales prices) and risk } \\
\text { measurement (market risk, operational risk, financial } \\
\text { risk). }\end{array}$ \\
\hline 10. & $\begin{array}{l}\text { Measurement of Feasibility and Risk } \\
\text { Level on Modern Embroidery Kebaya } \\
\text { Boutique Establishment in Jakarta }\end{array}$ & [15] & $\begin{array}{l}\text { This research explains two aspects of the feasibility study: } \\
\text { market aspect and technical aspect. Also, sensitivity } \\
\text { analysis and risk analysis. }\end{array}$ \\
\hline
\end{tabular}

The conceptual model is a chart that displays several factors or variables and becomes a conceptual model for analyzing research problems. The conceptual model is as follows.



Figure 3 - Conceptual Model

According to Figure 3, there are several critical interrelated factors in completing this research: market, technical, website design, and financial aspects. After analyzing these factors, it will conclude that it is feasible or not to do Pikyeum marketing through website media and analyze product sensitivity levels.

The first stage, the market aspect, aims to determine the Pikyeum consumers to estimate demand and income. Market aspect data can be determined based on the potential market, available, and demand forecast. Market aspect data were conducted qualitatively and quantitatively. The method of collecting qualitative data is indirect market observation. Quantitative data collection methods were surveys (sampling) to 5 major cities in Java and observation. Slovin's formula was used to determine the number of participants, as shown in the equation below:

$\mathrm{n}=\frac{\mathrm{N}}{1+\mathrm{Ne}^{2}}=\frac{12.949 .616}{1+12.949 .616 \times(0,1)^{2}}=99,99922778 \approx 100$ participants

Where $\mathrm{n}=$ sample size, $\mathrm{N}=$ population size, and $\mathrm{E}=$ error $(10 \%)$. The data was collected in Bandung, Jakarta, Tangerang, Malang, and Semarang Cities with 100 participants (15-64 years old). Survey data were analyzed using Corrected ItemTotal Correlation as a validity testing technique and Cronbach's Alpha as a reliability testing technique with the aid of the SPSS program.

Table 2 - Validity Test Result

\begin{tabular}{|l|r|r|r|r|}
\hline & $\begin{array}{c}\text { Scale Mean if } \\
\text { Item Deleted }\end{array}$ & $\begin{array}{c}\text { Scale } \\
\text { Variance if } \\
\text { Item Deleted }\end{array}$ & $\begin{array}{c}\text { Corrected } \\
\text { Item-Total } \\
\text { Correlation }\end{array}$ & $\begin{array}{c}\text { Cronbach's } \\
\text { Alpha if Item } \\
\text { Deleted }\end{array}$ \\
\hline Q1 & 17.67 & 5.819 & .512 & .814 \\
Q2 & 17.59 & 5.638 & .717 & .757 \\
Q3 & 17.68 & 6.119 & .575 & .796 \\
Q4 & 18.28 & 5.093 & .620 & .786 \\
Q5 & 17.94 & 5.390 & .673 & .765 \\
\hline
\end{tabular}

Information:

$\mathrm{Q} 1=$ There is a halal label

Q2 = Expiration date on the label

Q3 = Product taste

Q4 = Friendly service

Q5 = Product durability

*endangchumaidiyah@telkomuniversity.ac.id 
According to Table 2, The questionnaire distributed is valid because fulfills the criteria (Corrected Item-Total Correlation $\geq 0.30$, valid). Furthermore, reliability testing is carried out to determine the degree of consistency of the measured targets.

Table 3 - Reliability Test Result

\begin{tabular}{|r|r|}
\hline $\begin{array}{c}\text { Cronbach's } \\
\text { Alpha }\end{array}$ & N of Items \\
\hline .819 & 5 \\
\hline
\end{tabular}

Table 3 concluded that the data is reliable because the reliability coefficient of Cronbach's Alfa is $0.819>0.70$. Researchers use Cronbach's Alpha as a reliability testing technique because this technique is the most frequently used.

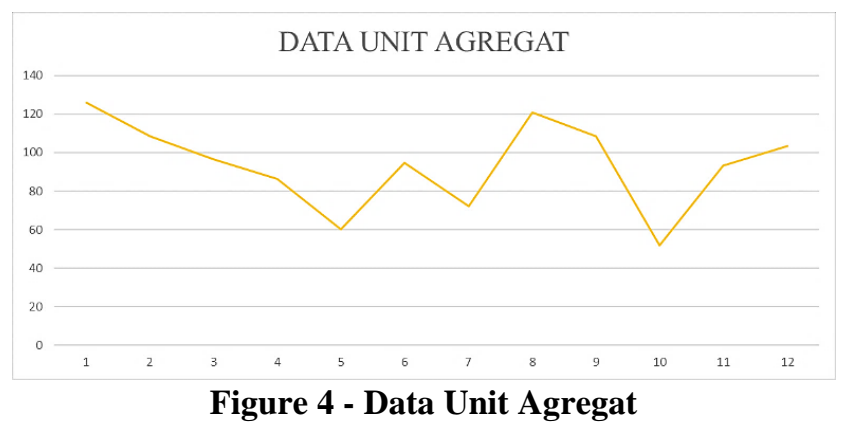

Estimated demand for Pikyeum is obtained from the forecasting method using Pikyeum offline store sales data in 2020. According to Figure 4, The pattern on the Pikyeum offline store sales data in 2020 is called the Seasonal Pattern. Forecast methods that are following seasonal data patterns are Single Moving Average (SMA), Double Moving Average (DMA), dan Weighted Moving Average (WMA). According to Table 4, The method with the Minimum Mean Square Error (MSE) value among the three methods is the Weighted Moving Average.

Table 4 - MSE Result

\begin{tabular}{cccccc}
\hline No. & Method & MSE & No. & Method & MSE \\
\hline 1. & SMA 2 & 889 & 5. & DMA 3x3 & 1186 \\
2. & DMA $2 \times 2$ & 1214 & 6. & DMA 3x4 & 1130 \\
3. & DMA 2x3 & 890 & 7. & DMA 4x3 & 1409 \\
4. & DMA 3x2 & 1729 & 8. & WMA & 818 \\
\hline
\end{tabular}

The second stage, the technical aspect, aims to know the investment costs and operational costs that the company will incur to do marketing through the website. The things that must be reviewed are determining the location, labor, equipment, operations, and raw materials. Technical aspect data were conducted quantitatively. Quantitative data collection methods were structured interviews with the owners of Pikyeum SME and field observations. Field observations were carried out at the Pikyeum SME location, Bandung Regency. Field observations and interviews were ascertained the location of the business, make Operation Process Chart (OPC), determine the number of workers needed, and know the raw materials and equipment needed.

The third stage, website design, aims to explain the flow of the system to be designed in the form of a system diagram method. In this study, there are three methods of system diagrams that will be used: Data Flow Diagrams (DFD), Use Case Diagrams, and Flowcharts.

The fourth stage, the financial aspect, conducts a more detailed analysis of the market, technical, and system design. Financial aspect data processing aims to assess the company's finances overall with the aid of Ms. Excel. The financial aspect includes analysis of asset investment cost, raw material and packaging cost, labor costs, machine electricity cost, PDAM cost, marketing cost, funding needs, income, profit loss, cash flow, and balance sheet.

A business is feasible when it provides profits to investors and business actors. The methods used to assess the feasibility in this study are: 


\section{Payback Period}

The payback period (PP) is used to measure the length of time it takes a company to recover its invested capital. If the investment capital recovery period is shorter than the economic life, the business is feasible. The following formula is used to calculate the payback period.

$\mathrm{PP}=($ Investment Value $) /($ Net Cash $) \times 1$ year.

If:

a. Payback period $<$ economic life, investment accepted.

b. Payback period $>$ economic life, investment rejected.

2. Net Present Value

Net Present Value (NPV) is a method used to calculate the difference between the present value of an investment and the present value of net cash receipts in the future. This method requires data on the amount of investment issued for the business and net cash flow per year according to the equipment's economic life used for the operation. The formula for calculating the Net Present Value is as follows:

$$
\begin{aligned}
& N P V=P V \text { Benefit }- \text { PV Cost. } \\
& N P V=\sum_{n=0}^{N}(R n-D n)\left(\frac{p}{f}, i \%, n\right)
\end{aligned}
$$

$\mathrm{Rn}=$ net cash flow in period $\mathrm{n}$

$\mathrm{p} / \mathrm{f}=\mathrm{p} / \mathrm{f}$ factor

$\mathrm{i}=$ interest

$\mathrm{n}=\operatorname{period} \mathrm{n}$

If:

a. NPV $>0$, investment accepts, and the company is feasible.

b. $\mathrm{NPV}<0$, investment rejects and the company are not feasible.

c. $\mathrm{NPV}=0$, the probability of the investment being received.

3. Internal Rate of Return (IRR)

Internal Rate of Return is a method used to calculate the interest rate equates to the present value of expected future cash flows, or cash receipts, by issuing an initial investment. The formula for calculating the Internal Rate of Return is as follows:

$$
\begin{aligned}
& \mathrm{IRR}=\mathrm{i}_{2}+\frac{\mathrm{NPV}_{1}}{\mathrm{NPV}_{1}-\mathrm{NPV}_{2}} \times\left(\mathrm{i}_{2}-\mathrm{i}_{1}\right) \\
& \mathrm{i}_{1}=1 \text { st interest rate } \\
& \mathrm{i}_{2}=2 \text { nd interest rate }
\end{aligned}
$$

The IRR assessment must compare the Minimum Attractive Rate of Return (MARR) value. MARR is the minimum value that a business must achieve.

a. If IRR > MARR, investment accepts.

b. If IRR $<$ MARR, investment rejects.

The fifth stage, assessing business feasibility based on several methods, namely the value of Net Present Value (NPV), Internal Rate of Return (IRR), and Payback Period. The result of these criteria will be a decision whether Pikyeum is worth running or not. 
The sixth stage, Sensitivity analysis, displays the impact of changes in factors or parameters. The sensitivity parameters analyzed in this study are 1) increase in the cost of raw materials and packaging, 2) increase in labor costs, 3) decrease in demand for Pikyeum products, and 4) decrease in the selling price of the product.

\section{RESULT AND DISCUSSION}

\subsection{Market Aspect}

This study collects market data to determine the potential market and available market using the method of filling out a questionnaire with the condition that the respondents are 15-64 years old and domiciled in Bandung, Jakarta Tangerang, Malang, and Semarang. The total population of these 5 cities is 12.949 .616 people. The following is the potential market and available market based on the Pikyeum variant.

Table 5 - Potential and Available Market

\begin{tabular}{ccc}
\hline Market & Percentage & Amount \\
\hline Potential market & $96 \%$ & $1.466 .933 \mathrm{~kg}$ \\
Available market & $91 \%$ & $1.334 .909 \mathrm{~kg}$ \\
\hline
\end{tabular}

There are $96 \%$ of respondents interested in product offerings, but $91 \%$ are willing to buy at IDR $22.500 /$ pcs with a weight of 150 gram. Data from several competitors is needed as a reference to determine the average weight of Peuyum chips per package. This research used the average weight of the three competitors is 118 grams per package. Based on the survey results, $69 \%$ of respondents buy Peuyeum chips once a year, $19 \%$ buy two times a year, and $12 \%$ buy more than two times a year. So, the researchers chose the largest percentage as a reference for calculating the repetition of consumers buying Peuyeum chips, which is one time in 1 year. The result is that the potential market yield is $1.466 .933 \mathrm{~kg}$ and the available market is $1.334 .909 \mathrm{~kg}$.

Based on the survey, $75 \%$ of respondents chose online stores and $25 \%$ offline stores. It can be concluded that the comparison of consumer interest in buying offline and online stores is 1:3. According to [16], data on e-commerce food categories and personal needs increased by $60 \%$. So, researchers are optimistic about increasing $20 \%$ online store demand in 2023-2026.

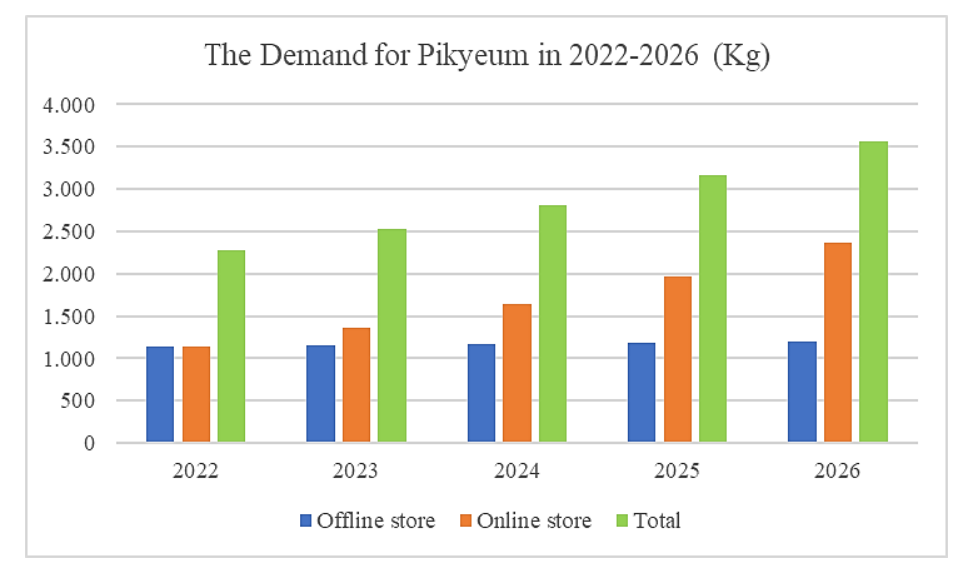

Figure 5 - The Demand for Pikyeum

According to Figure 5, The graph of the demand for Pikyeum with offline store sales data using the Weighted Moving Average (WMA) method. However, 2022 is the first time Pikyeum SME makes online sales, so demand online stores same with offline stores and prioritize product marketing. Based on the result demand for Pikyeum in 2022 is $2.280 \mathrm{~kg}$, 2023 is $2.523 \mathrm{~kg}, 2024$ is $2.812 \mathrm{~kg}, 2025$ is $3.156 \mathrm{~kg}$, and 2026 is $3.566 \mathrm{~kg}$.

According to [17], who studied the Consumer Behavior Track on March 20-27 (2020), it was found that there was a decrease in Indonesian people's behavior towards weekend walks, trips to malls, and holidays that offline sales targets might not be achieved. To overcome this problem, the researcher designed $20 \%$ of offline sales specifically for resellers with the special price so that offline sales can reach the target. 


\subsection{Technical Aspect}

The technical aspect is an aspect that reviews the technical business development process and operational process. Processing on the technical aspects is making the Operation Process Chart (OPC) and calculating the number of workers, machines, tools, facilities, raw materials, and packaging. The following is the standard time for each activity process.

Table 6 - Pikyeum SME Activities

\begin{tabular}{ccc}
\hline Map Number & Activity & Standard Time \\
\hline 01 & Production & 490 minutes \\
02 & Shipment & 145 minutes \\
\hline
\end{tabular}

Based on interviews with owners of Pikyeum SME and field observations, the standard time on production per production is 490 minutes, and shipment is 145 minutes. Each production can make $6 \mathrm{~kg}$ peuyeum chips.

Human resource management is very important in a company. By creating an organizational structure, Pikyeum SME can manage and consider the human resource needs to develop a good work system. The following is the organizational structure of Pikyeum SME. The long working hours of the Pikyeum SME are 8 hours per day and day work on MondayFriday.

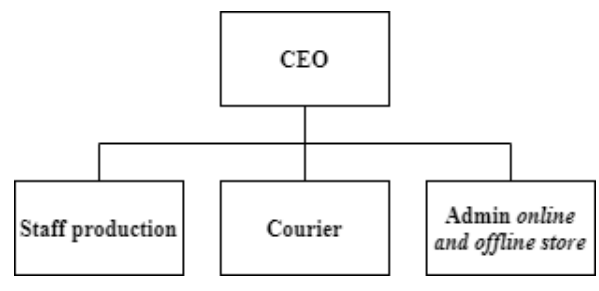

Figure 6 - Organizational Structure

In 2022-2024 the staff production needed is two people/day and in 2025-2026 is three workers/day. Meanwhile, the labor required for a courier is one person, and the admin store is three persons. Overtime is work carried out outside working hours. In 2023 and 2024, production employees will have to work overtime. The following is the calculation of overtime hours of production activities in 2023 and 2024.

Table 7 - Overtime Staff Production

\begin{tabular}{cc}
\hline Years & Overtime (hours) \\
\hline 2023 & 6 \\
2024 & 39 \\
\hline
\end{tabular}

Pikyeum SMEs need machines, equipment, and facilities to run a business based on their activities. The economic life of operational facilities is based on the regulation of the Minister of Finance number 96/PMK.03/2009. Trade Business License (SIUP) is a legal document for your business issued by the Regional Government. Trademarks function as identifying goods or services. Website as a forum for providing information to consumers and the process of buying and selling online. The following is an intangible investment of Pikyeum SME.

Table 8 - Intangible Investment

\begin{tabular}{cll}
\hline No. & \multicolumn{1}{c}{ Description } & Period \\
\hline 1. & SIUP & Forever \\
2. & Trademark & 10 years \\
3. & Website making & Forever \\
4. & Website maintenance & 1 year \\
\hline
\end{tabular}

Researchers carried out two calculations for designing a layout: calculating space in the facility and storage space. The space in the facility is calculated based on the dimensions of the facility and the machine. The warehouse is calculated 
based on productions per week (unit), the size of the box, and the shelves. After the two calculations are complete, the researcher can design a layout based on space, facilities, and the production process flow. The area needed for Pikyeum SME is $10 \times 14 \mathrm{~m}^{2}$.

The following is the total need for raw materials and packaging components based on product demand in 2022-2026. Chocolate and milk flavored sprinkles are calculated according to Pikyeum's request based on flavor variants: $42 \%$ chocolate, $30 \%$ original, and $28 \%$ milk. The original flavor does not have additional seasoning.

Table 9 - Raw Material

\begin{tabular}{lccccc}
\hline \multicolumn{1}{c}{ Description } & $\mathbf{2 0 2 2}$ & $\mathbf{2 0 2 3}$ & $\mathbf{2 0 2 4}$ & $\mathbf{2 0 2 5}$ & $\mathbf{2 0 2 6}$ \\
\hline Fresh peuyeum $(\mathrm{kg})$ & 570 & 752 & 761 & 771 & 780 \\
Wheat llour $(\mathrm{kg})$ & 760 & 1.002 & 1.014 & 1.028 & 1.040 \\
Tapioca flour $(\mathrm{kg})$ & 760 & 1.002 & 1.014 & 1.028 & 1.040 \\
Chocolate flavored seasoning $(\mathrm{kg})$ & 120 & 158 & 160 & 162 & 164 \\
Milk flavored seasoning $(\mathrm{kg})$ & 80 & 105 & 106 & 108 & 109 \\
Cooking oil (l) & 1.330 & 1.754 & 1.775 & 1.799 & 1.820 \\
\hline
\end{tabular}

Table 10 - Packaging

\begin{tabular}{lccccc}
\hline \multicolumn{1}{c}{ Description } & $\mathbf{2 0 2 2}$ & $\mathbf{2 0 2 3}$ & $\mathbf{2 0 2 4}$ & $\mathbf{2 0 2 5}$ & $\mathbf{2 0 2 6}$ \\
\hline Plastic packaging (unit) & 14.880 & 16.800 & 18.720 & 20.640 & 23.520 \\
HVS paper (ream) & 30 & 34 & 38 & 42 & 48 \\
Insulating glue (unit) & 197 & 223 & 248 & 273 & 311 \\
Box & 532 & 600 & 669 & 738 & 532 \\
Polymer plastic (pack) & 7.280 & 9.100 & 10.920 & 12.740 & 7.280 \\
\hline
\end{tabular}

\subsection{System Design}

Researchers used the Data Flow Diagrams (DFD), Use Case Diagrams, and Flowchart methods as the Pikyeum website system design. The consumer can access the website for 24 hours, but the admin processes orders according to the working hours of Pikyeum SME. 




Figure 7 - Data Flow Diagram

According to Figure 7, the Pikyeum website connects with admins, visitors, and consumers. The admin inputs admin login data, product data, delivery address data, delivery service data, order data, mod_bank data, confirmation data, and contact data. Meanwhile, visitors input registration data and product search data. Consumers input consumer login data, product search data, order data, consumer data, delivery address data, confirmation data, and contact data. After data is inputted, the Pikyeum website will receive all information, and the website can be accessed properly.

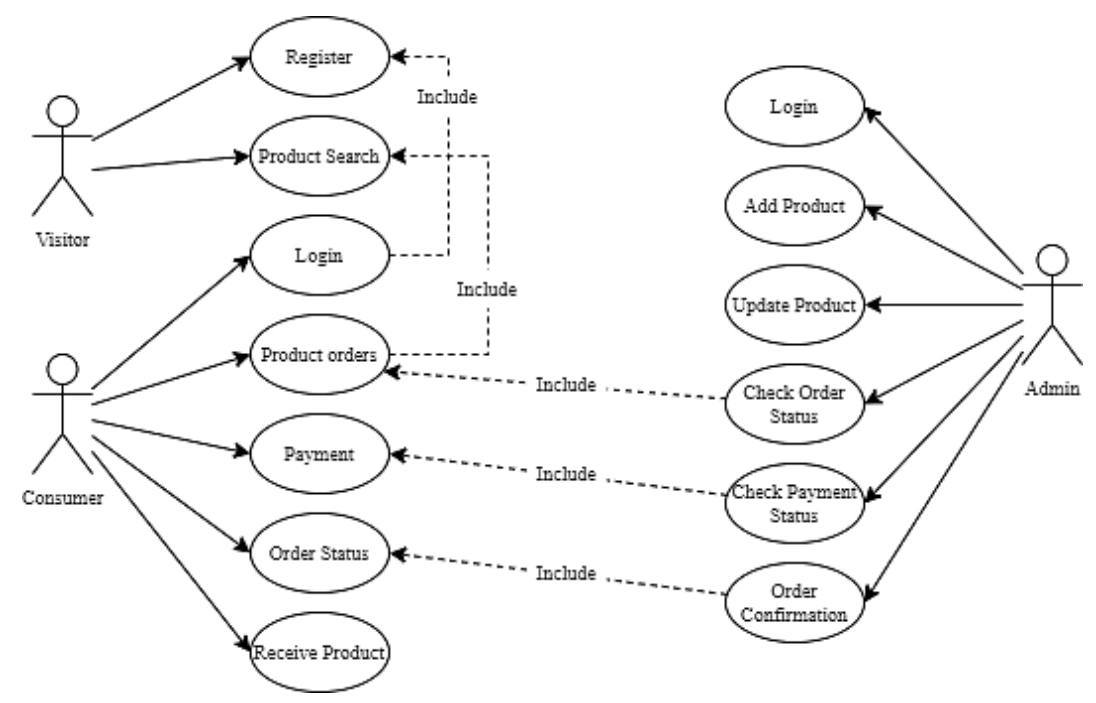

Figure 8 - Use Case Diagram

According to Figure 8, there are three actors on the Pikyeum website: admin, visitors, and consumers. There are two activities of visitors and consumers connected (register - log in and product search - product orders). Meanwhile, three admin and consumer activities are connected (product orders - check order status, payment - check payment status, and order status - order confirmation). 


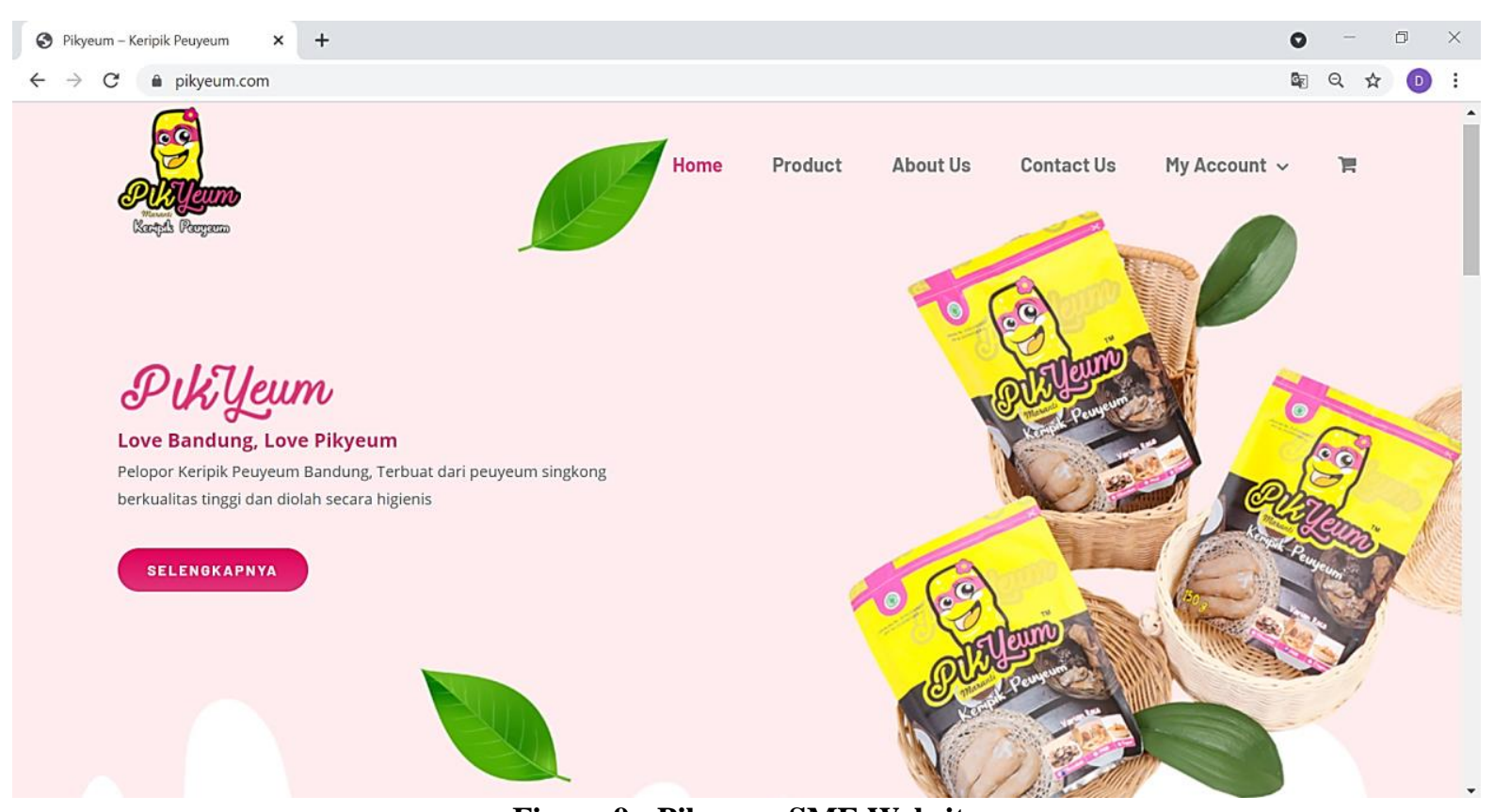

Figure 9 - Pikyeum SME Website

The website is a place to provide information to the public and purchase Pikyeum online. The website can be accessed in 24 hours, but the admin only processes orders during business hours. Pikyeum's working hours are Monday-Saturday at $09.00-16.00$. According to Figure 9, an overview of the Pikyeum website is based on the system design. Pikyeum SME website can be accessed through www.pikyeum.com.

\subsection{Financial Aspect}

Pikyeum SME can produce $6 \mathrm{~kg}$ of Peuyeum chips equivalent to $40 \mathrm{pcs}$ of Pikyeum in each production. The selling price of Pikyeum products to consumers is IDR 22.500/pcs. The following is a projection of the Pikyeum SME revenue graph for 2022-2026.

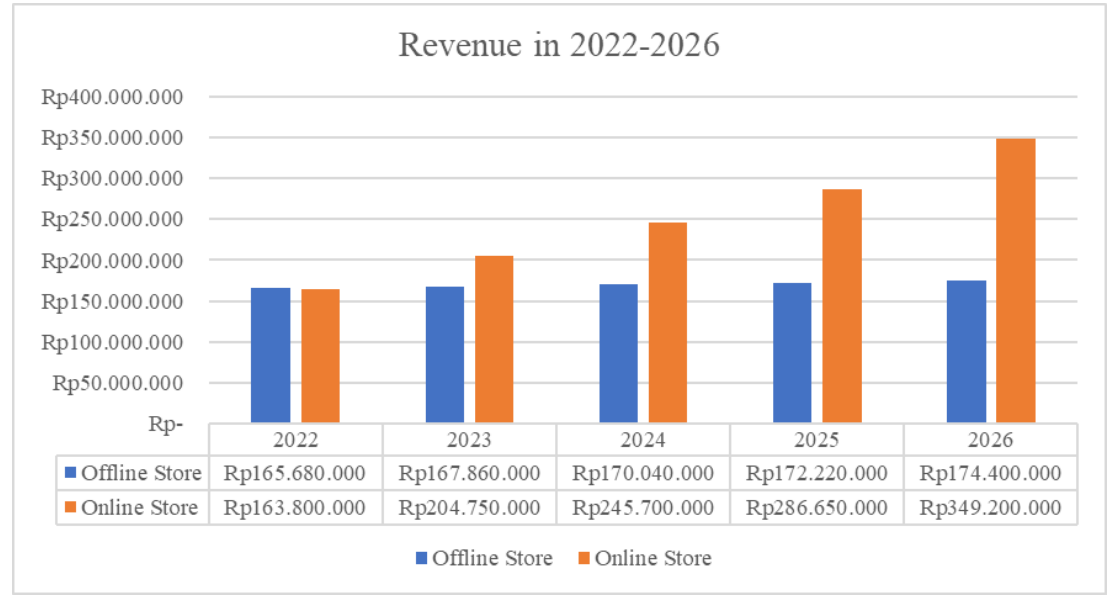

Figure 10 - Revenue

According to Figure 10, income has increased significantly every year. Revenue is earned from offline and online sales. $20 \%$ of offline store revenue comes from sales to resellers. The selling price of Pikyeum products to resellers is IDR 19.000/pcs. In the first year, Pikyeum SMEs revenue was IDR 329.480.000. Meanwhile, in 2023 IDR 372.610.000, 2024 is IDR 415.740.000, 2025 is IDR 458.870.000, 2026 is IDR 523.600.000. The provisions on SME tax payment obligations percentage follow government regulation Number 23 of 2018 (PPh Final PP 23).

\subsection{Feasibility and Sensitivity Analysis}

Feasibility analysis is an assessment of whether a business can provide profits to investors or business actors. Researchers used three methods in measuring feasibility: NPV, payback period, and IRR. Net Present Value (NPV) is calculated from the difference between the current investment value and the present value of net cash receipts in the future. 
Table 11 - Feasibility

\begin{tabular}{ccccccc}
\hline Years & 2021 & 2022 & 2023 & 2024 & 2025 & 2026 \\
\hline Period & 0 & 1 & 2 & 3 & 4 & 5 \\
\hline
\end{tabular}

Cash-out IDR 124.833 .997

Salvage value

IDR 26.591.144

Working capital

Cash in

IDR 17.130.578

IDR 48.354.012

IDR 61.386 .381

IDR 59.534 .412

IDR 67.348 .698

Net cash

-IDR 124.833.997 IDR 17.130.578

IDR 48.354 .012

IDR 61.386 .381

IDR 59.534.412

IDR 118.618.074

$\mathrm{p} / \mathrm{f}$ factor $(8,25 \%)$

0,924

0,853

0,788

0,728

IDR 212.557.917

\begin{tabular}{|c|c|c|c|c|c|}
\hline NPV & -IDR 124.833.997 IDR 15.825.014 & IDR 41.264.511 & IDR 48.393 .643 & IDR 43.356 .723 & IDR 143.000 .567 \\
\hline NPV Cumulative & -IDR 124.833.997 -IDR 109.008.983 & -IDR 67.744 .472 & -IDR 19.350 .829 & IDR 24.005.894 & IDR 167.006.461 \\
\hline
\end{tabular}

MARR

$8,25 \%$

NPV

IDR 167.006.461

Payback period

3,4 years

IRR

$36,70 \%$

According to Table 11, Bank Mandiri is a reference for the basic loan interest rate. Salvage value comes from the value of assets, and working capital comes from the cost of the company's initial three months. Sensitivity analysis displays the impact of changes in factors or parameters. The parameters in the sensitivity analysis are the cost of raw materials and packaging, labor costs, demand, and selling prices. The following is the result of sensitivity analysis.

Table 12 - Sensitivity

\begin{tabular}{cccccc}
\hline No. & \multicolumn{1}{c}{ Parameters } & Increase/Decrease & Persentase & NPV & Sensitive at \\
\hline 1. & Raw materials and packaging costs & Increase & $36 \%$ & IDR 3.388 .905 & $36,76 \%$ \\
& & & $37 \%$ & - IDR 1.094 .336 & \\
2. Labor costs & Increase & $23 \%$ & IDR 3.547 .606 & $23,51 \%$ \\
& & & $24 \%$ & - IDR 3.462 .741 & \\
3. Demand & Decrease & $15 \%$ & IDR 7.554 .923 & $15,63 \%$ \\
& & & $16 \%$ & - IDR 4.353 .605 & \\
4. Selling prices & Decrease & $11 \%$ & IDR 5.610 .939 & $11,34 \%$. \\
& & & $12 \%$ & - IDR 10.804 .688 & \\
\hline
\end{tabular}

\section{CONCLUSION}

Market data collection to determine potential and available markets using questionnaires in 5 major cities: Bandung, Jakarta, Tangerang, Malang, and Semarang. The total population of these five cities is 12.949.616 people. Seeing the increasing demand, Pikyeum carries out marketing strategies every year. The product marketing strategy carried out is holding a bazaar, using email marketing, and using media marketing services.

Technical and operational aspects such as raw materials, packaging, assets, and location can be feasible because they have been adjusted to the amount of production, labor, and working time. The asset investment cost is IDR 51.135.299 with working capital for three months IDR 67.348.698. The location of the Pikyeum SME is designed based on the production flow and assets owned with an area of 10x14 $\mathrm{m}^{2}$. Making the Pikyeum website costs IDR 2.500.000 with an 
extension fee of IDR 650.000/year. The website can be accessed 24 hours, but the admin processes orders only during business hours.

Based on the results of this research calculation, the NPV of Pikyeum SME is IDR 167.006.461. Then the investment is accepted because the company was feasible because the NPV value $>0$. The payback period is a business feasibility method used to measure the period required for the company to recover its invested capital. Based on the calculation results of this study, Pikyeum SME can recover capital within 3,4 years. The shortest economic life for the Pikyeum SME assets is 4 years, so the company is feasible because the recovery of investment capital is shorter than the economic life of assets. Internal rate of return is a business feasibility method used to compare profits when investing in other places. IRR value of the Pikyeum SME reached 36,70\%, and the Minimum Attractive Rate of Return (MARR) value based on the bank's interest rate was $8,25 \%$. It can be concluded that the business is feasible because of IRR > MARR. Sensitivity analysis is a method that pays attention to the percentage level limit on factors that affect business processes. The increase of raw materials and packaging costs shouldn't be more than 36,76\%. Meanwhile, the increase of labor cost shouldn't be more than 23,51\%. The demand decreases shouldn't be more than 15,63\% and selling prices shouldn't exceed $11,34 \%$. Pikyeum SME never sold products in an online store, and the company must do strong marketing to achieve sales targets. The company should consider selling Pikyeum products on the marketplace and using bank loans as a source of funds for Pikyeum SME. The location of the Pikyeum SME is not to be combined with the owner's house choosing the location close to the target market.

\section{Acknowledgement}

The authors offer their gratitude to the School of Industrial and System Engineering, Telkom University, for facilitating this research and to the reviewers who provided valuable inputs for the perfection of this scientific article.

\section{Disclaimer}

The authors whose names are written certify that they have no conflict of interest.

\section{REFERENCES}

[1] BPS, "Badan Pusat Statistik," 05 November 2020. [Online]. Available: https://www.bps.go.id/statictable/2014/09/08/950/rata-rata-konsumsiper-kapita-seminggu-beberapa-macam-bahan-makanan-penting-2007-2019.html.

[2] DISKOPUMKM, "MSME Data," October 2020. [Online]. Available: http://diskopumkm.bandung.go.id/page/informasi-umkm.

[3] S. Husnan and S. Muhammad, Studi Kelayakan Proyek Bisnis, Edisi Ke 5, Yogyakarta: UPP STIM YKPN, 2014.

[4] D. Purwana and N. Hidayat, Studi Kelayakan Bisnis, Depok: Rajawali Pers, 2016.

[5] A. Mujilan, Analysis and System Design, Madiun: Fakultas Ekonomi dan Bisnis Universitas Katolik Widya Mandala Mandiun, 2017.

[6] R. F. Lazuardi, L. Fitria and A. Bakar, "Feasibility Analysis of Mobile Carwash Business in Bandung," Jurnal Online Institut Teknologi Nasional, pp. 48-56, 2014.

[7] P. A. Wulandari, E. Chumaidiyah and F. Hasun, "Feasibility Analysis of RDA Hijab Business Development with Online and Offline Sales," Jurnal Mitra Manajemen (JMM Online), pp. 859-872, 2019.

[8] P. M. Fauzi, E. Chumaidiyah and N. Suryana, "Feasibility Analysis and Website Application Design for Digital Creative Photography Startups Based on Market Aspects, Technical Aspects and Financial Aspects," Jurnal INTECH Teknik Industri Universitas Serang Raya Vol 5, pp. 6066, 2019.

[9] R. H. Putra, E. Chumaidiyah and M. Rendra, "Street Food Business Feasibility Analysis for Modern Market Parking Area Utilization," Jurnal Ilmu Manajemen \& Bisnis - Vol 10, pp. 181-186, 2019.

[10] Z. and E. Chumaidiyah, "Feasibility Analysis of Rumah Tempe Zanada Establishment in Bandung Using Net Present Value, Internal Rate of Return, And Payback Period," in 1st International Conference on Industrial and Manufacturing Engineering, Medan, 2019.

[11] G. M. Hutasoit , E. Chumaidiyah and B. Praptono, "Feasibility Analysis of Culinary Business Cafe Nusantara Development in the Central of Jakarta," in 5th International Conference on Rural Development and Entrepreneurship, Yogyakarta, 2019.

[12] A. Z. Rahardja, E. Chumaidiyah and W. Tripiawan, "Feasibility Analysis on the Development of Steel Sheet Zinc Plated and Galvalum Production Factory PT. S Steel," in 1st International Conference on Industrial and Manufacturing Engineering, Medan, 2019.

[13] F. Nurazizah and E. Chumaidiyah, "Business Design and Feasibility of Puru Kambera Muslim Fashion Offline Store Establishment," in ICI_ME 2020, Medan, 2020.

[14] F. Rahmawati1 and E. Chumaidiyah, "Business Design and Risk Analysis of Sonja Coffee Shop with the Concept of Coworking Space," in ICI_ME 2020, Medan, 2020.

[15] R. W. Hanaa and E. Chumaidiyah, "Measurement of Feasibility and Risk Level on Modern Embroidery Kebaya Boutique Establishment in Jakarta," in ISIEM 12, Batu Malang, 2020.

[16] G. Nurdian, "Indonesian E-commerce 2020," January 2020. [Online]. Available: https://grahanurdian.com/e-commerce-indonesia-tahun-2020/. [Accessed 23 June 2021].

[17] D. Wulandari, "This is the Trend of Consumer Behavior During Covid-19," April 2020. [Online]. Available: https://mix.co.id/marcomm/newstrend/inilah-tren-perilaku-konsumen-selama-covid-19/. [Accessed 23 June 2021] 